\title{
Satisfaction of Saudi Nationals and Expats towards Loans by Banks in Eastern Province, Saudi Arabia
}

\author{
Mohammed Al Doghan \\ Department of Management, King Faisal University, Al hasa 31982, Saudi Arabia \\ Tel: 966-506-905-055Ｅ- mail: mdoghaan@gmail.com
}

Received: September 17, 2015 Accepted: October 12, 2015 Published: November 1, 2015

doi:10.5296/bms.v6i2.8324 URL: http://dx.doi.org/10.5296/bms.v6i2.8324

\begin{abstract}
The success of any business depends upon their effective and continuous operation which in-turn depends on their efficiency in meeting their financial requirement as finance is the life-blood of any business. At a globalized era in which we live, the business firms and individuals approach banks and financial institutions to avail loans to successfully operate in the competitive field. Marketing is a total system of business activities to plan, price, promote and distribute needs and satisfy customers to target markets in order to achieve organizational objectives. In this background of growing markets for financial services, increasing competition and improving the level of financial awareness and sophistication by the end users, both personal and corporate, the banks have to develop their marketing skill to maintain their market share and profitability levels. The changing face of banking industry has brought in new challenges and newer responsibilities to the bankers in Saudi Arabia. They have to function with new vigor and vitality in the significantly competitive banking business. Any failure on their part in keeping the eternal vigil is fraught with disastrous and devastating consequences.
\end{abstract}

Keywords: Business, Satisfaction, Customers, Financial service, Banking 


\section{Introduction}

Finance is vital for each and every activity of an individual or a concern. The success of any business firm depends upon their effective and continuous operation which in-turn depends on their efficiency in meeting their financial requirement. The growth, development and diversification activities also require financial assistance. In the present globalised era business firms, students, and individuals approach banks and financial institutions to avail loans to successfully operate in the competitive arena. The concept of marketing done by the banks has been generally viewed by various bank marketers as that part of the management activity, which seeks to direct the flow of banking services to select customers from a strategic perspective. A comprehensive explanation of marketing executed by the banks has been given by Deryk Weyner of Barclay's Bank and according to him bank marketing is "identifying the most profitable markets now and in the future, assessing the present and future needs of customers, setting the business and promoting them to achieve the plans - all in the context of the changing environment in the market". Thus, the implementations of marketing concepts by banks have to recognize that the needs of the customers are changing. Efforts should be made to widen and deepen the process of information flow to educate the customers on bank products. Unlike industrial marketing, banks offer a wide range of products and services to meet a variety of financial and related needs from different customers in various locations. Moreover banking has a special service of lending - one of its major products which is in a way leasing money. Banks provide loans for agriculture, industry, trade, commerce and personal needs of individuals.

\subsection{Statement of Problem}

Saudi banking is passing through a unique phase. To retain and improve profitability of banks in such a grim scenario needs Herculean efforts and the banks are desperately searching for the ways to improve their earnings. The consumer loans have sound security support, which appreciates with time and the level of non-performing assets in the case of consumer loans is very low. With very low post credit supervision costs, the margins become attractive, especially in a scenario of falling interest rates. Consumer loans for varying proposals like acquisition of consumer durables, for meeting travel, medical expenses offer great scope for credit absorption. As a result, all banks in the banking industry apply their own marketing skills to attract more customers. To ensure their competitive edge in future, they have to fight with rivals in terms of quality of their customer services.

\subsubsection{Review of Literature}

The involvement of financial with marketing has had a relatively short and turbulent history. Much research studies have been undertaken in the field of financial service marketing. The commercial banks in their administrated and over controlled set up were not concerned with market research. The working group on customer service (1977) noted that there was considerable ignorance about the facilities and services offered by banks and the roles they were required to play. Most bank customers are unaware of various schemes and services 
offered by banks. The group recommended educational campaigns to be carried out by banks illustratively and every customer of the bank should be provided with a booklet containing the range of services offered by banks. The survey conducted by the working group pointed out that by and large less educated people and females are far away from banks. Since developing banking habits is not a strategy only for social uplift but an equally important strategy for bank marketing and in the long run the committee took serious note on this finding. Churchil et al (1982) defined customer satisfaction as an attitude which is assessed by the sum of the satisfaction towards various attributes of the product or service. Turnbull (1982) examined the role of Branch Manager in the marketing of bank services. His study was done through personal interview with branch managers and tried to highlight the existing role of branch managers and how they perceived both their own role and their customer's needs. The knowledge and attitude of managers towards marketing and the communication process between himself and his customers were evaluated in this study. The survey demonstrated lack of understanding of the concept of marketing among branch managers. They had only a narrow view of marketing as majority of them equated marketing with selling. Many managers confessed that they lacked detailed knowledge of many of the services and they had only a general understanding of the range of services. More than 70 percent of the respondents recognized the importance of good personal relationship with their customers. Archana Mathur (1988) in her study on service quality in public banks indicated that customers face the problems of delayed service, lack of proper guidance and discrimination by bank staff.

The banks assure quality services to their customers inorder to make them to enjoy the latest wide range of financial facilitates with minimum transactioninst.(Rod MA.N,2008)

Studies done by Naser (1999), Al Tamimi and Al Amiri (2003),Okumus (2005),Abdulkader and norizan (2009),Osman(2009),Hussain and Leo (2009) and Golmohammadi and Jahandideh (2010), Abduh (2011), Abduh (2012) and Bashir (2013) in different countries confiem the dimension of banking service quality. The dimension od banking service quality are profitability, security, competence, Bank customer relationship, Accessibility, Cost quality dimension etc.

\subsubsection{Research Gap}

A detailed analysis of the review of literatures related to marketing activities was undertaken on banks to market their products and customer satisfaction towards the procedures followed by banks while sanctioning loans indicates that there is no research conducted in Eastern province, Saudi Arabia to analyze the customer satisfaction towards marketing of loans by banks. Hence the present study is framed to analyze the customer satisfaction towards marketing of loans by banks with reference to Eastern Province which would fulfill the above research gap. 


\section{Objectives}

This study has the following objectives:

1. To study the various marketing activities implemented by banks

2. To know the overall satisfaction level of the customers towards the marketing of loans by banks in Eastern province, Saudi Arabia.

3. To analyze the level of satisfaction of the customers on factors considered by the banks while sanctioning loans.

4. To provide useful suggestions to various banks to improve their quality of service and implement new attractive marketing strategies.

\subsection{Methodology}

The study is empirical in nature based on the survey method. The whole data required for the study were collected in three stages. The primary data relating to the satisfaction level of the respondents on the various dimensions towards the marketing of loans by banks were collected by interviewing the respondents selected for the study with the help of an interview schedule. The researcher has used stratified random sampling technique to identify banks in Eastern province, Saudi Arabia. Further, the researcher has used purposive sampling technique to select hundred and seventeen customers who have availed loans from selected banks in Eastern province, Saudi Arabia

\subsubsection{Framework of Analysis}

For the purpose of the comprehensive analysis of data, appropriate statistical techniques and tools were used based upon the nature of data and the relevance of the statistical technique. The overall satisfaction of the bank customers and satisfaction on various aspects of marketing such as services provided by banks, rates charged by the banks, the methods adopted while sanctioning of loan by banks, support provided by bank staff at the time of applying loans, publicity of the banks, relationship maintained by bank staffs after sanctioning loan, promotion offers given by the banks, public campaign organized by banks, online application of loan, repayment of loan amount to the banks, transparency in interest and principal calculations, various charges for interest calculations, disbursement stage in bank loan and privilege banking advantage have been analysed by the researcher. The mean scores and range scores of each group of the respondents on various aspects were calculated. To analyze the overall satisfaction of the respondents towards marketing of loans mean scores, t-test, analysis of variance, correlation analysis and multiple regression analysis were used. The satisfaction of the respondents towards various aspects of marketing of loans was done using t- test, path analysis. Analysis of variance with post hoc test was done to find out the group in which the non-significant factors have been identified over other variables in the group. Garret Ranking method was used to identify the source through which customers got the information about loans and the factors that induced the customers to borrow. 


\subsubsection{Hypotheses}

In tune with the second and third objectives, hypotheses have been formulated that various independent variables such as age, sex, marital status, education, occupation, employment, nature of family, members in the family, income, banks from where the loans are availed and the opinion of the respondents on the lending banks influence the following dependent variables:

a. Overall satisfaction of the respondents on the marketing strategies adopted by the banks.

b. Satisfaction towards services provided by the banks.

c. Satisfaction towards rates charged by the banks.

d. Satisfaction towards the methods adopted while sanctioning of loan by banks.

e. Satisfaction towards the support provided by bank staff at the time of applying loans.

f. Satisfaction towards publicity of the banks

g. Satisfaction towards relationship maintained by bank staff after sanctioning loan.

h. Satisfaction towards the promotion offers given by the banks

i. Satisfaction towards public campaign organized by bank.

j. Satisfaction towards online application of loan.

k. Satisfaction towards the repayment of loan amount to the banks.

1. Satisfaction towards the transparency in interest and principal calculations.

m. Satisfaction towards various charges for interest calculations.

n. Satisfaction towards disbursement stage in bank loans.

o. Satisfaction towards privilege banking advantage.

\section{Analysis and Interpretation}

The sample respondents were divided into three groups on their respective scores. The respondents with the satisfaction scores were grouped as highly satisfied, moderately satisfied and lower satisfaction. The analysis indicates that out of 117 sample respondents, $15.60 \%$ derived high level of satisfaction, $15.70 \%$ derived moderate level of satisfaction and the remaining $68.70 \%$ derived lower level of satisfaction on various aspect of banking loans. The respondents were divided into two groups in accordance with the gender group to which they belong. The respondents were grouped as 'male' respondents and 'female' respondents. $85.5 \%$ fall under male group of respondents. $14.5 \%$ fall under female group of respondents.. The respondents were divided into three groups in accordance to the age group of the respondents. The groups are the age group below 30 years, 30years to 50 years and above 50 years. 
The respondents were divided into two groups in accordance to the marital status of the respondents. $88 . \%$ who are married respondents. $12 \%$ were unmarried respondents. The mean satisfaction score of the respondents with school level qualification is higher than the respondents qualified with Undergraduate, postgraduate and Professional qualification. And hence it can be inferred that the qualification with school level qualification respondents derived higher level of satisfaction on the banking loans. It further indicates that the percentage of respondents with low level of satisfaction is the lowest (9.4\%) and the percentage of respondents with the high level of satisfaction is the highest $(6.5 \%)$ among the respondents who have post graduation. It can be inferred that the relationship between the qualified respondents and the level of satisfaction of the respondents on banking loan is significant. The mean satisfaction score of the professionally occupied respondents is higher than the other category of occupation such as private employment, self employment, administrative and others. And hence it can be inferred that the respondents with professional occupation derived higher level of satisfaction on the banking loans. It further indicates that the percentage of respondents with low level of satisfaction is the lowest (7.3\%) among professionally occupied respondents and the percentage of respondents with the high level of satisfaction is the highest (4.4\%) among the self employed respondents. It can be inferred that the relationship between the occupational status of the respondents and the level of satisfaction of the respondents on banking loan is not significant.

\section{SIGNIFICANCE OF DIFFERENCE IN THE OVERALL SATISFACTION SCORES BETWEEN GROUPS - 'T' TEST}

In order to find out whether the difference in the overall satisfaction scores between the groups is significant, ' $t$ ' test. The result of ' $t$ ' test indicates that there exists a significant difference in the mean satisfaction score among:

i) The gender of the respondents

ii) The marital status of the respondents

iii) The respondents nature of family

To analyse the objective whether there is any significant difference in the satisfaction level on various dimensions between male and female respondents, married and unmarried respondents and joint and nuclear nature of family respondents ' $t$ ' test is presented in the table below.

\section{Null Hypothesis: (HO)}

Male and female, married and unmarried and joint and nuclear family respondents give on an average same level of opinion on overall satisfaction towards banking loans.

\section{Alternative Hypothesis: (H1)}

Male and female, married and unmarried and joint and nuclear family respondents do not give on an average same level of opinion on overall satisfaction towards banking loans. 
Table 1.

\begin{tabular}{|c|c|c|c|c|c|c|c|}
\hline Factor & Group & Mean & S.D & $\mathbf{Z}$ & DF & $\begin{array}{l}\text { Table } \\
\text { value }\end{array}$ & Result \\
\hline \multirow{2}{*}{ Sex } & Male & 4.0142 & .60928 & \multirow{2}{*}{.643} & \multirow{2}{*}{615} & \multirow{2}{*}{1.00} & \multirow{2}{*}{ Accept } \\
\hline & Female & 3.9851 & .51522 & & & & \\
\hline \multirow{2}{*}{$\begin{array}{l}\text { Marital } \\
\text { Status }\end{array}$} & Married & 3.9906 & .59542 & \multirow{2}{*}{-.302} & \multirow{2}{*}{613} & \multirow{2}{*}{1.00} & \multirow{2}{*}{ Accept } \\
\hline & Unmarried & 4.0052 & .46450 & & & & \\
\hline \multirow{2}{*}{$\begin{array}{l}\text { Nature of } \\
\text { family }\end{array}$} & Joint & 3.9744 & .57802 & \multirow{2}{*}{-.833} & \multirow{2}{*}{615} & \multirow{2}{*}{1.00} & \multirow{2}{*}{ Accept } \\
\hline & Nuclear & 4.0131 & .54852 & & & & \\
\hline
\end{tabular}

Since the table value is greater than the calculated value considering level of significance 0.05 the null hypotheses is accepted. On the basis of this from the table is concluded that male and female, Married and unmarried customers and customers under joint and nuclear family had overall satisfaction towards banking loans.

\section{SIGNIFICANCE OF DIFFERENCE IN THE MEAN SATISFACTION SCORES BETWEEN THE GROUPS - ANOVA}

Since there are more than two groups in the case of age group, educational qualification, occupation and respondents employed in, so to compare the groups on the basis of their mean values ANOVA technique is applied. The result of analysis of variance indicates that there exists a significant difference in the mean satisfaction scores among:

i) The respondents age group

ii) The respondents who vary in terms of educational qualification

iii) The respondents who are classified based on occupation category

iv) The respondents vary based on s where they are employed in.

Null Hypothesis: (H0)

Respondents belonging to 1) various age groups, 2) occupation, 3) education level and 4) employed in give on an average same level of opinion on overall satisfaction towards banking loans.

Alternative Hypothesis: (H1)

Respondents belonging to 1) various age groups, 2) occupation, 3) education level and 4) employed in do not give on an average same level of opinion on overall satisfaction towards banking loans. The table value is greater than the calculated value based on level of significance in case of Age, Qualification, occupation and Employed in. Thus it can be concluded that age, qualification, occupation and employment influence the overall satisfaction of banking loans.

OVERALL SATISFACTION TOWARDS MARKETING ACTIVITIES ADOPTED BY BANKS INDEX FOR THE SAMPLE RESPONDENTS - MULTIPLE REGRESSION ANALYSIS 
Multiple regression analysis has been applied in order to find out the simultaneous effect of independent variables on the dependent variables i.e., the overall satisfaction of the respondents on various marketing mix strategies adopted by banking that render financial assistance. This analysis helps to find the extent of dependence of dependent variable on independent variables. This helps to find which independent variable influence the dependent variable effectively. In order to find the casual relationship between the satisfaction over various dimensions under study and the overall satisfaction of the respondents, multiple regression is used. A multiple regression equation was constructed using the various independent variables such service provided, rates charged, methods adopted, support provided, publicity, relationship maintained by bank staff after sanctioning loan, promotion offers, public campaign, online application, repayment of loan amount to the banks, transparency in interest and principal calculations, various charges for interest calculations, disbursement stage in bank loans and privilege banking advantage. Among the various independent variables included in this analysis, 5\% significance level is being showed. The following table gives the coefficient of each dimensions and its significance level.

Table 2.

\begin{tabular}{|c|c|c|c|c|c|c|}
\hline & & \multicolumn{2}{|c|}{ Unstandardized Coefficients } & \multirow[b]{2}{*}{ 't' value } & \multirow{2}{*}{$\begin{array}{l}\text { Sig. } \\
\text { value }\end{array}$} & \multirow{2}{*}{ Significance } \\
\hline \multicolumn{2}{|c|}{ Model } & $\mathrm{B}$ & Std. Error & & & \\
\hline 1 & Overall satisfaction & 1.502 & .222 & 6.755 & .000 & Not significant \\
\hline & Service provided & .029 & .006 & 4.652 & .000 & Not significant \\
\hline & Rates charged & .001 & .007 & .105 & .916 & Significant \\
\hline & Methods adopted & .067 & .012 & 5.530 & .000 & Not significant \\
\hline & Support provided & .025 & .008 & 3.239 & .001 & Not significant \\
\hline & Publicity & .003 & .004 & .809 & .419 & Significant \\
\hline & Relationship & -.066 & .006 & -10.707 & .000 & Not significant \\
\hline & Promotion offers & .045 & .009 & 4.839 & .000 & Not significant \\
\hline & Public campaign & -.033 & .006 & -5.404 & .000 & Not significant \\
\hline & Online application & .011 & .007 & 1.504 & .133 & Significant \\
\hline & Repayment of loan & .079 & .007 & 10.900 & .000 & Not significant \\
\hline & Transparency of interest & -.026 & .007 & -3.911 & .000 & Not significant \\
\hline & $\begin{array}{l}\text { Charges for interest } \\
\text { calculation }\end{array}$ & -.005 & .002 & -2.399 & .017 & Not significant \\
\hline & Disbursement stage & -.010 & .008 & -1.197 & .232 & Significant \\
\hline & $\begin{array}{l}\text { Privilege banking } \\
\text { advantage }\end{array}$ & -.068 & .022 & -3.102 & .002 & Not significant \\
\hline
\end{tabular}

Significance at $5 \%$ level.

In the above table except for the dimensions Rates charges, Publicity, Online application of loan and Disbursement stage the other coefficients are significant. Thus if the satisfaction towards these dimensions increases the overall satisfaction also increases significantly. This 
model is a good fit, which is evident from the $r$ square value, 0.774 . That is $77.4 \%$ of variability in the dependent variable is explained by the independent variables. Also the $\mathrm{F}$ value in ANOVA table is significant $(\mathrm{F}=125.578$, sig $=0.000)$

The regression equation is

Overall

$1.502+0.029(\mathrm{~V} 1)+0.001(\mathrm{~V} 2)+0.067(\mathrm{~V} 3)+0.025(\mathrm{~V} 4)+0.03(\mathrm{~V} 5)-0.066(\mathrm{~V} 6)+0.045(\mathrm{~V} 7)-0.033($

$\mathrm{V} 8)+0.011(\mathrm{~V} 9)+0.079(\mathrm{~V} 10)-0.026(\mathrm{~V} 11)-0.005(\mathrm{~V} 12)-0.010(\mathrm{~V} 13)-0.068(\mathrm{~V} 14)$

Where V1=service provided, V2=Rates charged, V3=Methods adopted, V4=Support provided, V5=Publicity, V6=Relationship , V7=Promotion offers , V8=Public campaign , V9=Online application, V10=Repayment of loan , V11=Transparency of interest , V12=Charges for interest calculation, V13=Disbursement stage, V14=Privilege banking advantage.

From the above equation it is understood that methods adopted and repayment of loan influences overall satisfaction significantly higher than other independent variables where as relationship negatively influence overall satisfaction.

\section{SIGNIFICANCE OF DIFFERENCE IN THE MEAN SCORES BETWEEN THE GROUPS - ANOVA}

In order to find out whether the difference in the mean scores between the groups is significant, analysis of variance is applied and the result is presented. Since there are more than two groups in the case of age group, educational qualification, occupation and respondents employed in ANOVA technique is used for the purpose of comparison the groups on the basis of their mean values.

\section{OVERALL SATISFACTION INDEX OF THE SAMPLE RESPONDENTS TOWARDS THE MARKETING ACTIVITIES - CORRELATION ANALYSIS}

To analyse the relationship between two variables - with one independent and one dependent variable correlation analysis is being applied. Thus to find the correlation between the overall satisfaction and the other variables, correlation analysis has been applied, which is being presented in the table

$\mathrm{A}=$ Overall satisfaction of the respondents, $\mathrm{B}=$ service provided, $\mathrm{C}=$ Rates charged, $\mathrm{D}=$ Methods adopted, $\mathrm{E}=$ Support provided, $\mathrm{F}=$ Publicity $\mathrm{G}=$ Customer relation, $\mathrm{H}=$ Promotional offer, I=Public Campaign, J= Online application, $\mathrm{K}=$ Repayment of loan, $\mathrm{L}=$ Transparency in interest and principal calculation, $\mathrm{M}=\mathrm{Charges}$ for interest calculation, $\mathrm{N}=$ Disbursement Stage and $\mathrm{O}=$ Privilege banking advantage.

The below table shows the relationship between satisfaction and factors leading to satisfaction with the level of overall satisfaction of the respondents who are the customers of the selected banks in Eastern province, Saudi Arabia. Correlation values between the variables are mentioned in the above table. The above table shows that based on pearson 
correlation the value which correlates significantly the overall satisfaction with the service provided is.703, with rates charged is.643, with methods adopted is.667, with support provided is.663. with publicity is.528, with relationship maintained is.247, with promotion offers is.193, with public campaign is.361, with online application is.270, with repayment of loan amount is.436, with transparency in interest and principal calculation is.205, with charges for interest calculation is.361, with disbursement stage is.417 and with privilege banking advantage is.711 which indicates that the overall satisfaction is significantly positively correlated with other variables. Overall satisfaction and its factors are positively correlated with the level of satisfaction. This implies that if the score of one variable increases the overall satisfaction also increases significantly. The other factors of satisfaction such as service provided, rates charges, Methods adopted, Support provided, Publicity, Customer relation, Promotional offer, Public Campaign, Online application, Repayment of loan, Transparency in interest and principal calculation, Charges for interest calculation, Disbursement Stage and Privilege banking advantage positively correlated with the level of satisfaction. Hence there is a significant relationship between satisfaction and its factors.

Table 3. Correlation Matrix for Level of Satisfaction of the Respondents towards the Marketing Activities

\begin{tabular}{|c|c|c|c|c|c|c|c|c|c|c|c|c|c|c|c|}
\hline variable & A & $\mathrm{B}$ & $\mathrm{C}$ & $\mathrm{D}$ & $\mathrm{E}$ & $\mathrm{F}$ & $\mathrm{G}$ & $\mathrm{H}$ & $\mathrm{I}$ & $\mathrm{J}$ & $\mathrm{K}$ & $\mathrm{L}$ & $\mathrm{M}$ & $\mathrm{N}$ & $\mathrm{O}$ \\
\hline \multirow[t]{2}{*}{ A } & 1 & $.703^{* *}$ & $.643^{* *}$ & $.667^{* *}$ & $.663^{* *}$ & $.528^{* *}$ & $.247^{* * *}$ & $.193^{* *}$ & $.361^{* *}$ & $.270^{* *}$ & $.436^{* *}$ & $.205^{* *}$ & $.361^{* *}$ & $.417^{* *}$ & $.711^{* *}$ \\
\hline & & .000 & .000 & .000 & .000 & .000 & .000 & .000 & .000 & .000 & .000 & .000 & .000 & .000 & .000 \\
\hline \multirow[t]{2}{*}{ B } & $.703^{* *}$ & 1 & $.787^{* *}$ & $.902^{* *}$ & $.884^{* * *}$ & $.740^{* *}$ & $.637^{* * *}$ & -.008 & $.642^{* *}$ & $.656^{* *}$ & $.506^{* *}$ & $.416^{* *}$ & $.540^{* *}$ & $.685^{* *}$ & $.807^{* *}$ \\
\hline & .000 & & .000 & .000 & .000 & .000 & .000 & .847 & .000 & .000 & .000 & .000 & .000 & .000 & .000 \\
\hline \multirow[t]{2}{*}{$\mathrm{C}$} & $.643^{* *}$ & $.787^{* *}$ & 1 & $.764^{* *}$ & $.764^{* * *}$ & $.555^{* *}$ & $.538^{* * *}$ & $.353^{* *}$ & $.731^{* *}$ & $.562^{* *}$ & $.644^{* *}$ & $.618^{* *}$ & $.629^{* *}$ & $.725^{* *}$ & $.716^{* *}$ \\
\hline & .000 & .000 & & .000 & .000 & .000 & .000 & .000 & .000 & .000 & .000 & .000 & .000 & .000 & .000 \\
\hline \multirow[t]{2}{*}{ D } & $.667^{* *}$ & $.902^{* * *}$ & $.764^{* *}$ & 1 & $.831^{* * *}$ & $.742^{* *}$ & $.609^{* *}$ & $-.124^{* *}$ & $.574^{* *}$ & $.595^{* *}$ & $.418^{* *}$ & $.343^{* *}$ & $.452^{* *}$ & $.652^{* * *}$ & $.771^{* *}$ \\
\hline & .000 & .000 & .000 & & .000 & .000 & .000 & .002 & .000 & .000 & .000 & .000 & .000 & .000 & . 000 \\
\hline \multirow[t]{2}{*}{ E } & $.663^{* *}$ & $.884^{* *}$ & $.764^{* *}$ & $.831^{* *}$ & 1 & $.767^{* *}$ & $.724^{* *}$ & .014 & $.690^{* *}$ & $.695^{* *}$ & $.511^{* *}$ & $.347^{* *}$ & $.529^{* *}$ & $.526^{* *}$ & $.632^{* *}$ \\
\hline & .000 & .000 & .000 & .000 & & .000 & .000 & .737 & .000 & .000 & .000 & .000 & .000 & .000 & .000 \\
\hline \multirow[t]{2}{*}{$\mathrm{F}$} & $.528^{* *}$ & $.740^{* * *}$ & $.555^{* *}$ & $.742^{* *}$ & $.767^{* *}$ & 1 & $.709^{* *}$ & $-.082^{*}$ & $.592^{* * *}$ & $.587^{* *}$ & $.537^{* *}$ & $.288^{* *}$ & $.354^{* *}$ & $.576^{* *}$ & $.585^{* *}$ \\
\hline & .000 & .000 & .000 & .000 & .000 & & .000 & .041 & .000 & .000 & .000 & .000 & .000 & .000 & .000 \\
\hline \multirow[t]{2}{*}{ G } & $.247^{* *}$ & $.637^{* *}$ & $.538^{* * *}$ & $.609^{* *}$ & $.724^{* *}$ & $.709^{* *}$ & 1 & -.025 & $.726^{* *}$ & $.735^{* *}$ & $.656^{* *}$ & $.508^{* *}$ & $.442^{* *}$ & $.571^{* *}$ & $.341^{* * *}$ \\
\hline & .000 & .000 & .000 & .000 & .000 & .000 & & .531 & .000 & .000 & .000 & .000 & .000 & .000 & .000 \\
\hline \multirow[t]{2}{*}{$\mathrm{H}$} & $.193^{* *}$ & \#\#\# & $.353^{* *}$ & $-.124^{* *}$ & .014 & $-.082^{*}$ & \#\#\# & 1 & $.263^{* *}$ & $-.248^{* *}$ & $.520^{* *}$ & $.544^{* *}$ & $.386^{* *}$ & $.214^{* *}$ & $.175^{* *}$ \\
\hline & .000 & .847 & .000 & .002 & .737. & .041 & .531 & & .000 & .000 & .000 & .000 & .000 & .000 & .000 \\
\hline \multirow[t]{2}{*}{ I } & $.361^{* *}$ & $.642^{* *}$ & $.731^{* *}$ & $.574^{* *}$ & $.690^{* *}$ & $.592^{* *}$ & $.726^{* *}$ & $.263^{* *}$ & 1 & $.568^{* *}$ & $.703^{* *}$ & $.643^{* *}$ & $.597^{* *}$ & $.686^{* *}$ & $.477^{* *}$ \\
\hline & .000 & .000 & .000 & .000 & .000 & .000 & .000 & .000 & & .000 & .000 & .000 & .000 & .000 & .000 \\
\hline \multirow[t]{2}{*}{$\mathrm{J}$} & $.270^{* *}$ & $.656^{* *}$ & $.562^{* *}$ & $.595^{* *}$ & $.695^{* *}$ & $.587^{* *}$ & $.735^{* *}$ & $-.248^{* *}$ & $.568^{* *}$ & 1 & $.385^{* *}$ & $.414^{* *}$ & $.320^{* *}$ & $.587^{* *}$ & $.313^{* *}$ \\
\hline & .000 & .000 & .000 & .000 & .000 & .000 & .000 & .000 & .000 & & .000 & .000 & .000 & .000 & .000 \\
\hline \multirow[t]{2}{*}{ K } & $.436^{* *}$ & $.506^{* *}$ & $.644^{* * *}$ & $.418^{* *}$ & $.511^{* *}$ & $.537^{* *}$ & $.656^{* *}$ & $.520^{* *}$ & $.703^{* *}$ & $.385^{* *}$ & 1 & $.694^{* *}$ & $.545^{* *}$ & $.632^{* * *}$ & $.512^{* *}$ \\
\hline & .000 & .000 & .000 & .000 & .000 & .000 & .000 & .000 & .000 & .000 & & .000 & .000 & .000 & .000 \\
\hline
\end{tabular}




\section{MInstitute Macrothink}

\begin{tabular}{|c|c|c|c|c|c|c|c|c|c|c|c|c|c|c|c|}
\hline \multirow[t]{2}{*}{$\mathrm{L}$} & $.205^{* *}$ & $.416^{* *}$ & $.618^{* *}$ & $.343^{* *}$ & $.347^{* *}$ & $.288^{* *}$ & $.508^{* * *}$ & $.544^{* *}$ & $.643^{* *}$ & $.414^{* *}$ & $.694^{* *}$ & 1 & $.643^{* *}$ & $.752^{* *}$ & $.395^{* *}$ \\
\hline & .000 & .000 & .000 & .000 & .000 & .000 & .000 & .000 & .000 & .000 & .000 & & .000 & .000 & .000. \\
\hline \multirow[t]{2}{*}{ M } & $.361^{* *}$ & $.540^{* *}$ & $.629^{* *}$ & $.452^{* *}$ & $.529^{* *}$ & $.354^{* *}$ & $.442^{* *}$ & $.386^{* *}$ & $.597^{* *}$ & $.320^{* *}$ & $.545^{* *}$ & $.643^{* *}$ & 1 & $.514^{* *}$ & $.449^{* *}$ \\
\hline & .000 & .000 & .000 & .000 & .000 & .000 & .000 & .000 & .000 & .000 & .000 & .000 & & .000 & .000 \\
\hline \multirow[t]{2}{*}{$\mathrm{N}$} & $.417^{* *}$ & $.685^{* *}$ & $.725^{* *}$ & $.652^{* *}$ & $.526^{* *}$ & $.576^{* *}$ & $.571^{* *}$ & $.214^{* * *}$ & $.686^{* *}$ & $.587^{* *}$ & $.632^{* *}$ & $.752^{* *}$ & $.514^{* *}$ & 1 & $.659^{* *}$ \\
\hline & .000 & .000 & .000 & .000 & .000 & .000 & .000 & .000 & .000 & .000 & .000 & .000 & .000 & & .000. \\
\hline \multirow[t]{2}{*}{$\mathrm{O}$} & $.711^{* *}$ & $.807^{* *}$ & $.716^{* *}$ & $.771^{* *}$ & $.632^{* *}$ & $.585^{* *}$ & $.341^{* *}$ & $.175^{* *}$ & $.477^{* *}$ & $.313^{* *}$ & $.512^{* *}$ & $.395^{* *}$ & $.449^{* *}$ & $.659^{* *}$ & 1 \\
\hline & .000 & .000 & .000 & .000 & .000 & .000 & .000 & .000 & .000 & .000 & .000 & .000 & .000 & .000 & \\
\hline
\end{tabular}

Source: Primay Data

\section{Suggestions}

Suggestions are offered by the researcher for improving the satisfaction level of the respondents towards the marketing of loans by the banks. These suggestions include those ideas offered by the sample respondents. The suggestions are listed below:

Majority of respondents think that explanations given by staff members regarding various schemes are not sufficient. So the bank staff at first should have a thorough knowledge about various schemes, and it would be convenient to give proper explanations to customers and satisfy them. Bank managers must aim higher than a mere achievement of customer satisfaction. With customers placing greater demands and competitive conditions forcing banks to accede to them, the banks must take adequate measures to empower their employees to constantly exceed their expectations. Any customer will see to it that they are confident enough to avail loans from a particular bank. They may consider reliability of the banks when compared to other banks to avail loans since the transaction involves huge sum of amount, which deals with the trust worthiness of the banks. The customers not only consider the reliability factor but also consider the security factor. As security plays a vital role in each and every banking activity the bankers can expose the reliability of their banks and provide good security to the funds which are involved in the process of availing loans.

The bankers can showcase their products so that it would attract huge customer impact since the right product offer and right communication can exert a positive impact on the level of satisfaction. They can showcase their products by providing attractive product displays. Most of the customers would search and choose the banks that provide lesser mortgages. The bankers can represent the higher authorities who fix up the targets in order to consider the customer expectation which would attract the customers towards the banks for availing loans. Majority of the respondents have the opinion that the service charges levied on them at the time of sanctioning of loans are considerably high. Therefore, the banks can reduce the service charges which they impose on customers while sanctioning of loans. The respondents too feel that part of the amount sanctioned is being paid back to the bank for the various charges made by the banks. The bankers can try to reduce the percentage of service charges by planning accordingly and this would attract more customers. Customers complaints can be approached and attended to by the bankers effectively. If the complaints are being attended to 
effectively the customers would gain some confidence towards that particular bank.

Most of the respondents stated that the bankers just say as word of mouth about various offers they are providing, but practically seeing through, the customers are not offered with those offers. In order to avoid such drawbacks the bankers can improve the offers that they provide to the customers and see to that the offers reach the customers on time. Each and every bank can come forward to organize public campaign so that the customers can come to know about the banks and the facilities available in that particular bank and various other factors under one roof. Hence the customers need not travel long by wasting their time to step in each and every bank for gathering details. As ours is a fast growing economy the customers feel that carrying out any transaction near to the place of their business operation would be convenient and to satisfy the customers for their convenience the bankers can go in for technological developments such as social network advertising, sending timely emails, SMS marketing and can also avail facility to the customer to apply and avail loans through online. Branches can be adequately equipped with hardware and support systems.

\section{Conclusion}

The study has given the researcher an experience in the sense that it has identified the overall satisfaction, level of satisfaction and satisfaction on various factors of the respondents in Eastern province, Saudi Arabia regarding the loans facilities offered by the banks. It is hoped that this type of study and the suggestions contained therein will be useful to the banks thereby increasing the level of satisfaction of respondents of this while availing loan facilities. It can be concluded that age, qualification, occupation and employment influence the overall satisfaction of banking loans. factors of satisfaction such as service provided, rates charges, Methods adopted, Support provided, Publicity, Customer relation, Promotional offer, Public Campaign, Online application, Repayment of loan, Transparency in interest and principal calculation, Charges for interest calculation, Disbursement Stage and Privilege banking advantage positively correlated with the level of satisfaction

\section{References}

Abduh, M. (2011). Islamic banking service quality and withdrawal risk: The Indonesian experience. International Journal of Excellence in Islamic Banking and Finance, 1(2), 1-15. http://dx.doi.org/10.1108/17538391211216811

Abduh, M., Kassim, S., \& Dahari, Z. (2012). Customer Satisfaction and Switching Behavior in Islamic Banking: Evidence from Indonesia. School of Doctoral Studies (European Union) Journal, 4, 209-215. http://dx.doi.org/10.4197/islec.22-2.7

Abduh, M., Kassim, S., \& Dahari, Z. (2013). Factors influence switching behavior of Islamic bank customers in Malaysia. Journal of Islamic Finance, 2(1), 12-19. http://dx.doi.org/10.12816/0001113

Al-Tamimi, H. A. A. (2003). Analysing service quality in the UAE Islamic banks. Journal of Financial Services $\quad$ Marketing, $\quad 8(2), \quad 119-132$. 
http://dx.doi.org/10.1057/palgrave.fsm.4770112

Bashir, M. S. (2013). Analysis of Customer Satisfaction with the Islamic Banking Sector: Case of Brunei Darussalam. Asian Journal of Business and Management Sciences, 2 (10): 38-50. Berry, L. P. (1985). Quality counts in services, too. Business Horizons, May-June, 44-52. http://dx.doi.org/10.1787/saeo-2014-graph30-en

Chakravarthi, A., \& Srikant, A. (2005). Marketing Strategies of Banks in Saudi Arabia, The ICFAI Journal of Services Marketing, ICFAI Press, Hyderabad, December. http://dx.doi.org/10.1108/08876049710176006

Churchil, J. R. (1982). An Investigation into the Determinants of customer satisfaction, Journal of Marketing Research, 19(4), 7-19. http://dx.doi.org/10.2307/3151722

Deryk Weyner, Quoted by Neylor and Mc Iver, Marketing Financial services by Banks, p.5.

Gary. H. R. (1987). Quality Service, a low cost profit strategy. Bank Marketing, September, 10-12. http://dx.doi.org/10.1108/02652329310045729

Hashim, N. A. (2010). The effect of corporate image, customer perceived value, relationship quality, and switching intention among Islamic banking customer in Malaysia. Business Management Quarterly Review, 1(4), 60-74.

Hossain, M. A. (2009). Customer perception on service quality in retail banking in Middle East: the case of Qatar. International Journal of Islamic and Middle Eastern Finance and Management, 2(4), 338- 350. http://dx.doi.org/10.1108/17538390911006386

Malyadri. P. (1988). Commercial Banks in the Customer service - A Study, Banking finance, June, pp.10-12.Talwar R.K., Working Group on Customer Service in Banks, Reserve Bank of Saudi Arabia, Bombay, 42, 112.

Naser, K. J. K. (1999). Islamic banking: a study of customer satisfaction and preferences in Jordan. International Journal of Bank Marketing, 17(3), 135-150. http://dx.doi.org/10.1108/02652329910269275

Norizan, A. K. (2009). Measuring perceived service quality in Qatari Islamic banks. Journal for International Business and Entrepreneurship Development, 4, 1-2, 90-106. http://dx.doi.org/10.1504/jibed.2009.022531

Oh, H. (1999). Service quality, customer satisfaction and customer value: an holistic perspective. International Journal of Hospitality Management, 18(1), 67-82. http://dx.doi.org/10.1016/s0278-4319(98)00047-4

Okumus, S. H. (2005). Interest-free banking in Turkey: A study of customer satisfaction and bank selection criteria. Journal of Economic Cooperation, 26(4), 51-86.

Oliver, R. A. (1989). Consumer perceptions of interpersonal equity and satisfaction in transactions: a field survey approach. Journal of Marketing, 53(April), 
21-35. http://dx.doi.org/10.2307/1251411

Osman, A. (2009). Customer satisfaction in Malaysian Islamic banking. International Journal of Economics and Finance, 1(1), 197-202. http://dx.doi.org/10.5539/ijef.v1n1p197

Turnbull, P. W. (1982). The Role of Branch Bank Manager. European Journal of Marketing, 16(3), 31-36. http://dx.doi.org/10.1108/eum0000000004836

Verma, D. P. S., \& Hema, I. (2001). Market-Orientation in Commercial Banks - A Study of Selected Banks in Delhi, Vision, July-December, pp.7-14. http://dx.doi.org/10.1177/097226290100500203

Vijaya, K. T. (1999). Customer Satisfaction - Potential base to success in Competitive Banking, IBA Bulletin, 21(12), 31-37.

William, A. (2004). Managing Customer Value, When is more better, ICFAI Reader, ICFAI Press.

\section{Copyright Disclaimer}

Copyright for this article is retained by the author(s), with first publication rights granted to the journal.

This is an open-access article distributed under the terms and conditions of the Creative Commons Attribution license (http://creativecommons.org/licenses/by/3.0/). 